\title{
サリチル酸塩の肺生理学的意義に関する研究
}

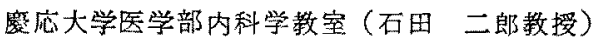

岡崎敬得

\section{STUDIES ON THE PULMO-PHYSIOLOGICAL ASPECTS OF THE EFFECTS OF SALICYLATES}

\author{
BY \\ Takashi Okazaki \\ Department of Internal Medicine, School of Medicine, Keiō University
}

(Prof.: J. Ishida)

\begin{abstract}
梗概 肺不全患者（主しして慢性肺気腫招よび濕性肋膜炎患者）の治療の対策の一つとして，サ リチレート大量投與による効果を主として心肺諸動態を中心に檢討し，1)換気量, 酸素徰取量の増 加, 動脈血炭酸ガス分圧の低下, 動脈血 $\mathrm{H}$ 斿よび酸素飽和度の上昇なぞガズ血液分布障害の改善学

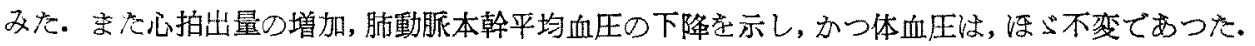
2)しふしながら，换気量，酸素攝取量扔よび心拍出量の增加にもかつわらず，動眽血孷酸ガス分

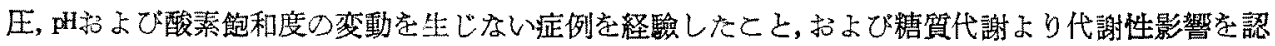
めたてとは, 肺不全患者の Anoxemia 怙よび Hypercapnia 改善する治潦として, 必ずしす有

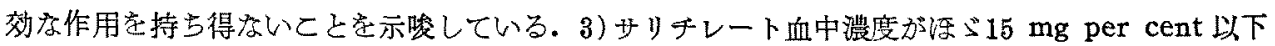

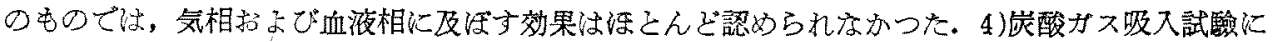

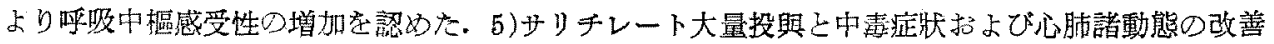

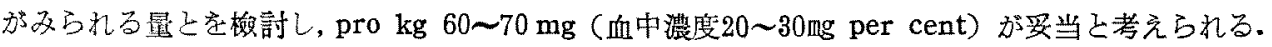
6)サリチレート大量，長期投與により，下垂体副緊系が刺激されているという結果老得た。
\end{abstract}

はじめに

近年肺生理学のいちじるしい発達とともに，肺 不全患者の治療の対策としていろいろの力法が研 究されつつあるが，われわれはこつに長い間Antipyretica，または Analgetica として親しまれ てきた Salicylate を険討してみた。本㸞はとき に Kusmaul の大呼吸をきたし，ときにいわゆ る Salicylic dyspnea を招く場合もあることは 從来から知られていたが，最近リウマチ性疾患に たいするコーチゾン療法の普及とともに本海の大 量投与により過剩換気を惹起することが認めら れ，この成因について現在まで主として血液ガ
ス・酸塩基平衡より，また呼吸中枢よりいろいろ の報告が出されてきだ 6). 過剩換気(の結果，呼 吸性アルカロージスを惹起し5)8)，また一方，動脈 血 $\mathrm{CO}_{2}$ 分圧上昇にたいする呼吸中枢感受性が増 加することにより778)13)，サリテル酸塩の大量投 与が肺不全患者の治潦の対策として新しく見直さ れつつある799〜12)。

かっる観点より，眠不全患者にたいしてサリチ ル酸劑大量投与時の变動およびその使用効果を， 主として心肺諸動態を中心にして観察したので報 告する。

\section{症例ならびに検查方法}

症例は慶応義熟大学病院内科に入院した患者の 
う亏, 片側湿性肋膜炎 6 例，慢性肺気腫 12 例，気 管支昖張症 4 例，計 22 例であり，次の 3 群に分け て観察した。

第 I 群（長期経口投与の影響）：慢性肺気腫 4 例, 片側湿性肋膜炎 6 例, 気管支挔張症 3 例, 計 13例であり，このうち症例 No. 1 No. 9 につ いて, acetyl salicylic acid を経口的に 1 日量 2.0〜 5.5g を分 4 で6 時間ごとに 7 日間連続投 与し，その投与前，中および後において主として 気相方よび血液ガス・酸塩基平衡を中心として観 繁した。また症例 No. 10〜No. 13までは acetyl salicylic acid 1 日量 $4.0 \sim 4.5 \mathrm{~g}$ を分 4 にて連 綂 7 日間服用の前および後において，右心カテ一 テリゼイション施行のもと心肺諸動態を観察し た。

第 II 群（短期点滴静注の影響）： Sodium salicylate $4.0 \sim 6.0 \mathrm{~g}$ 生理的食塩水 $200 \sim 300$ ccに溶解し，これを30〜40分間にわたり点滴静注 を㧍こない，静注前および静注後20分，40分およ び60分にわたり右心カテーテリゼイション施行の もと心肺諸動態を観短した，症例は慢性肺気腫 3 例，気管支昖張症 1 例である。

第群（1回投与と $\mathrm{CO}_{2}$ 吸入の影響）：acetyl salicylic acid 2.5〜 3.5 g 1 回経口投与 1 時間前後の影響と，このさい，同時に約 $4 \%$ の炭 酸分ス吸入試験を実施し，サリチル酸劑大量投与 時の呼吸中枢の炭酸ガスに対する感受性を, 主と， して気相，血液相および換気力学を中心として観 察した，症例は慢性肺気腫 5 例である。

\section{検查方法}

第工群では上腕動脈より勤脈血採血と同時に呼 気採取を実施した。また第 I 群の症例 No.10〜

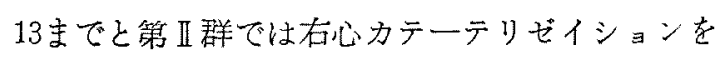
施行し，カテーテルを肺動脈本幹に固定した。

Cournand 型勤脈獍置針を上腕動脈または股 動脈に滒刺固定し，動脈血を採血し，同時に肺勤 脈本幹に固定したカテーテルより湿合静脈血を採
取した、また採血と同時に呼気採取をうこなつた。 第看群では acetyl salicylic acid 1 回経口投与 前および投与後 1 時間において，呼気，動脈血採 血と同時に, 食道内汪法による換気力学について 観蓉した。.

脑動脈圧は Statham 製 $\mathrm{P} 23 \mathrm{Db}$ 電気血圧計で 測定した. ガス分析は Van Slyke-Neill の法に より血液ガスを, Scholander 微量ガス分析装置 により気体ガスの分析をした，血液 pH は Cambridge のガラス電極pH計で測定した。気流量の測 定は Lilly の Flowmeter を用いこれに電気的 integrator を接続して換気量を積算し,胸腟内压 変化は食道内圧法を用い, Statham 1050 P23B の圧力計により測定し，気流，娎気量および食道 内任変化を Sanborn 社製の Polyvisorecorder により同時記録した。，心拍出量は Fick の理論式 を用い，また有効肺胞換気率，有效肺胞血流率の 算出はわれわれの方法によつた。

血獎（清）サリチル 酸塩濃度定量は，Ferric Chloride 法により測定した。

\section{検查成績}

1. 第 I 群 (長期経口投与の影響)：長期経口 投与例は表 1 および表 2 の第 I 群計13例で，ての う症例 No. 8 および No. 9 は acetyl salicylic acid 1 日量 $2.0 \sim 3.0 \mathrm{~g} 6$ 時間ごと7 日間 連涜服用した。このさいの Salicylate の血中濃 度は 17〜18mg per cent および12〜14mg per cent であつた。症例 No. 2 は acetyl salicylic acid 1 日量 $5.5 \mathrm{~g} 6$ 時間ごと 5 日間連続投与し た症例で, Salicylate の血中濃度は 36〜38mg per cent に達し，服用5 日にして中等度の悪心 および食欲減退が認められ，同時に耳鳴，難聽 および軽度の頭痛を訴えたもので，以後 acety1 salicylic acid 1 日量 $4.0 \mathrm{~g}$ 岁 6 洔間ごとに減量 したところ, 血中 Salicylate 濃度は, ほぐ $30 \mathrm{mg}$ per cent となり軽度の食欲不振のほか副作用は 消失した。その他の症例では 1 日量 3.5〜 $5.0 \mathrm{~g}$ を敏日 6 時間ごとに 7 日間連続腿用しここさい 
表1、第1群 アセチルサリチル酸経口投与辰期の影䅉

\begin{tabular}{|c|c|c|c|c|c|c|c|c|c|c|c|c|c|c|c|c|c|c|}
\hline 虚例然号 & 牙名 & B.S.A & 病 各 & 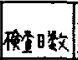 & 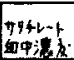 & 唩吸铱 & 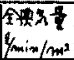 & 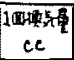 & 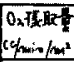 & $\begin{array}{l}\mathrm{CO}_{2}, \mathrm{HL} \\
\mathrm{Cy}_{\mathrm{min}} / \mathrm{m}^{2}\end{array}$ & 咊吸交 & 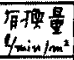 & $\begin{array}{c}\mathrm{PH} \\
\mathrm{PH}\end{array}$ & 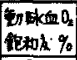 & 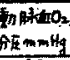 & 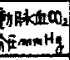 & 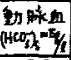 & 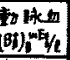 \\
\hline & & \multirow{4}{*}{1.450} & \multirow{4}{*}{ 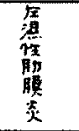 } & 草 & 0 & 16 & 0.12 & 554 & 141 & 113 & 0.80 & 2.12 & 7380 & 830 & 62 & 50.0 & 23.5 & 41,2 \\
\hline & & & & 30 & 34 & 17 & 7.25 & 618 & 159 & 144 & 0.91 & 3.38 & 7.420 & 86.0 & 73.0 & 36.5 & 23.0 & 443 \\
\hline & & & & $6 E$ & 30 & 16 & 7.80 & 698 & 152 & 154 & 1.01 & 3.65 & 7.401 & 96.5 & 91.0 & 36.5 & 220 & 44.0 \\
\hline & & & & \begin{tabular}{r|}
78 \\
$\pi y+6 r$
\end{tabular} & $\begin{array}{c}24 \\
5.092879\end{array}$ & 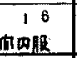 & 7.30 & 658 & 180 & 145 & 0.81 & 3.10 & 7.370 & 94.5 & 179.0 & 38.5 & 24.8 & 46.3 \\
\hline \multirow{5}{*}{2} & & \multirow{5}{*}{1.420} & \multirow{5}{*}{ 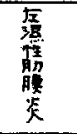 } & 前 & 0 & 10 & 5.14 & 380 & 124 & 121 & 0.86 & 2.27 & 7.341 & 93.0 & 74.0 & 44.8 & 21.5 & 44.0 \\
\hline & & & & 38 & 36 & 16 & 6.00 & 534 & 139 & 133 & 0.90 & 3.00 & 7.380 & 95.0 & 820 & 39.7 & 22.8 & 45.0 \\
\hline & & & & 58 & 38 & 18 & 7.58 & 520 & 157 & 130 & 0.88 & 3.17 & 7.380 & 95,0 & 83.0 & 37.6 & 23.3 & 45.0 \\
\hline & & & & 78 & 30 & 21 & 6.36 & 532 & 158 & 130 & 0.83 & $3.2^{6}$ & 7.372 & 94.7 & 82.5 & $34: 0$ & 23.5 & 45,3 \\
\hline & & & & \multicolumn{3}{|c|}{ 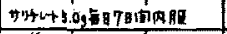 } & & & & & & & & & & & & \\
\hline \multirow{5}{*}{3} & & \multirow{4}{*}{1.302} & \multirow{4}{*}{ 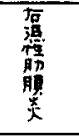 } & 前 & 0 & 10 & 4.42 & 377 & 129 & 117 & 0.00 & 1.78 & 7.224 & 87.0 & 66.0 & 56.8 & 21.2 & 40.0 \\
\hline & & & & 30 & 21 & 17 & 6.74 & 450 & 150 & 148 & 0.07 & 2.01 & 7.329 & 13.7 & 78.0 & 51.0 & 21.5 & 43.5 \\
\hline & & & & 58 & 20 & 16 & 5.49 & 549 & 181 & 154 & 0.96 & 2.76 & 7,332 & 91.7 & 80.0 & 48.2 & 21.8 & 420 \\
\hline & & & & $\begin{array}{l}78 \\
40+45\end{array}$ & 22 & 17 & 6.84 & 586 & 100 & 140 & 0.83 & 2.7 .3 & 7.328 & 91.5 & 79.0 & 48.4 & 23.0 & 42,8 \\
\hline & & \multirow{5}{*}{1,400} & \multirow{5}{*}{ 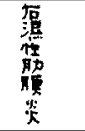 } & 前 & 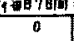 & 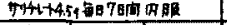 & $4.7=$ & 367 & 129 & & & 2.18 & 76 & 92.3 & 80.0 & 50.5 & 203 & 40.2 \\
\hline & & & & 30 & 20 & 18 & $\frac{4.1 E}{5.42}$ & 422 & 135 & 122 & $\frac{0.80}{0.81}$ & 2.27 & 7.361 & 95.0 & 83.0 & 46.0 & 26,5 & $\frac{40.2}{45.4}$ \\
\hline & & & & 50 & 24 & 19 & 6.32 & 392 & 135 & 118 & $0.8 \mathrm{~B}$ & 2.14 & 7.368 & 95.0 & 83.0 & 44.5 & 25.0 & 46,2 \\
\hline & & & & 70 & 23 & 13 & 5.14 & 378 & 137 & 110 & 0.87 & 2.28 & 7,372 & 94.0 & 820 & 44.0 & 26.3 & 46.0 \\
\hline & & & & \multicolumn{3}{|c|}{ 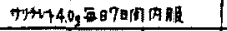 } & & & & & & & & & & & & \\
\hline \multirow{5}{*}{5} & & \multirow{5}{*}{1.565} & \multirow{5}{*}{ 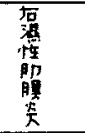 } & 肯前 & 0 & 17 & 5.65 & 471 & 128 & 117 & 0.92 & 2.00 & 7,382 & 92.0 & 820 & 49,5 & 24.3 & 45.4 \\
\hline & & & & 30 & 20 & 18 & 6.46 & 690 & 148 & 148 & 0,98 & 2.70 & 7.442 & 940 & 84.0 & 44.0 & 23.0 & 48.3 \\
\hline & & & & 60 & 81 & 12 & 6.85 & 585 & 156 & 141 & 0.81 & 2.83 & $7.47 !$ & 94.1 & 88.0 & 42,5 & 24,7 & 46,2 \\
\hline & & & & 2.8 & 20 & 18 & 0.58 & 574 & 157 & 135 & 0,82 & 2.67 & 7.472 & 93.8 & 90.0 & 43.0 & 25.0 & 48.0 \\
\hline & & & & $79+1-44$ & Q9287010 & 91918 & & & & & & & & & & & & \\
\hline & & & $\sqrt{6}$ & 前 & D & $1^{8}$ & 6.54 & 47.2 & 110 & 110 & 0.96 & 1.6 .6 & 7.299 & 84.0 & $6 \pi .0$ & 58.0 & 23.5 & 46.3 \\
\hline & & & tit & 30 & 23 & 16 & 8.24 & 584 & 158 & 161 & 0.00 & 2.67 & 7,370 & 86.0 & 79.5 & 50,0 & 24.8 & 47.4 \\
\hline & & 1.532 & $\frac{1}{5}$ & 58 & 21 & 18 & 0.88 & 668 & 150 & 147 & 0.91 & 2.80 & 7.362 & 89.3 & 81.0 & 48.5 & 23.2 & 45.8 \\
\hline & & & st & \begin{tabular}{c|}
78 \\
$94+6+40$
\end{tabular} & \begin{tabular}{cc|}
2 & 1 \\
0,58 & 0
\end{tabular} & $\begin{array}{c}16 \\
1 \text { 服 }\end{array}$ & 0.04 & 664 & 154 & 141 & 0.82 & 2.43 & 7.376 & 89.8 & 79.0 & 45.9 & 25.0 & 48.2 \\
\hline & & & & 前 & 0 & 16 & 5.86 & 524 & 148 & 130 & 0.98 & 2.37 & 7.380 & 83.0 & 62.0 & 50.0 & 23.5 & 41,2 \\
\hline & & & & 38 & 24 & 10 & 8.05 & 730 & 196 & 180 & 0.83 & 3.35 & 7.420 & 860 & 680 & 46,5 & 22.6 & 43.5 \\
\hline & & 1.450 & $\begin{array}{l}\text { 症 } \\
\end{array}$ & $\begin{array}{r}70 \\
+44+14\end{array}$ & $\begin{array}{c}23 \\
4.546078\end{array}$ & 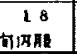 & 7.80 & 628 & 191 & 172 & 0.03 & 3.28 & 7.448 & 85.5 & 66.0 & 45.8 & 23.8 & 42.6 \\
\hline & & & & 前 & 0 & 18 & 4.77 & 372 & 131 & 124 & 0.86 & 2.48 & 7.402 & 93.0 & 84.0 & 42,3 & 22,3 & 41.6 \\
\hline & & & & 38 & 18 & 17 & 4.85 & 408 & 125 & 124 & 0.08 & 2.74 & 7.380 & 924 & 820 & 38.4 & 24.5 & 44.3 \\
\hline & & 1.401 & & 88 & 11 & 18 & 5.01 & 300 & 130 & 128 & 0.84 & 2.77 & 7.410 & 94,0 & 83.0 & 39.3 & 25.0 & 42.3 \\
\hline & & & & $7 y+63$ & 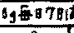 & ब胜 & & & & & & & & & & & & \\
\hline & & & & 告 & 0 & 22 & 6.48 & 527 & 119 & 82.0 & 0.69 & 2.62 & 7.251 & 93.0 & 81.0 & 46.0 & 20.0 & 41.0 \\
\hline & & 1.424 & 堂 & 3日 & 12 & 22 & 7,50 & 572 & 150 & 111 & 0.74 & 2.76 & 7.248 & 940 & 84.0 & 50.0 & 22,0 & 41.0 \\
\hline & & & & 58 & 14 & 19 & 7.14 & 572 & 131 & 121 & 0.12 & 2.50 & 7.240 & 95.5 & 84.5 & 505 & 23.0 & 42.0 \\
\hline & & & & $74+2+20$ & 0,597816 & 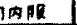 & & & & & & & & & & & & \\
\hline
\end{tabular}

の Salicylate 血中濃度は20〜33mg per cent で あつた（表1，表2).

acetyl salicylic acid 7 日間経口投与のさいの 換気諸量の变動は，症例 No. 8 おうび No. 9 を除き，Salicylate 血中濃度が20mg per cent 以上に達した症例では，いすれも分時換気量，

1 回換気量の著明な増加を認め，また酸素消費 量, 炭酸ガス排出量もいちじるしく増加した。 ま た有効肺胞換気波，有効肺胞血流率もともに上昇 し，血液，ガス分布障害の改善を示している.

動脈血血液ガス方よび酸塩基平衡の裂動は, 症 例 No. 8 および No. 9 を除き，哩脈血酸素飽 和度, 動脈血酸素分圧は増加し, 動脈血孷酸ガ
分王は著明に低下した。 また動脈血 $\mathrm{pH}$ は，症例 No. 8 おむ゙ No. 9 を除き，いすれも著明に上 昇した。また $\left(\mathrm{B}_{\mathrm{B}}^{+}\right)_{\mathrm{B}}$ は一定の傾向なく，(HC$\mathrm{O}^{-}{ }^{3}$ )流不変加，や>減少の傾向がみられた。

以上の成績より Salicylate 血中濃度がほぶ20 mg per cent 以上に達した症例（症例 No. 8 および No. 9 を除く) では, hyperventilation の結果招来される， respiratory alkalosis の様 相を呈した。また症例 No. 8 および No. 9 に は気相，血液ガス・酸塩基平衡に上述の傾向はみ られなかつた。

心拍出量は表 2 , 第 I 群症例 No. 10 No. 13 まで，いずれも著明に堌加したが，このさいの肺 
表 2、第1群 アセチルサリチル酸経口投与長期の影釷

\begin{tabular}{|c|c|c|c|c|c|c|c|c|c|c|c|c|c|c|c|c|c|c|c|c|c|}
\hline 倒: & 氏 名 & 促要面稀 & 瘏名 & \multicolumn{2}{|c|}{ 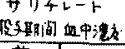 } & 呼吸拲 & 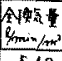 & 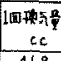 & 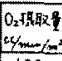 & 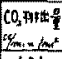 & 有理 & 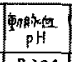 & 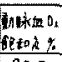 & 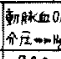 & 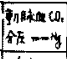 & 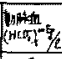 & 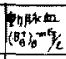 & $\begin{array}{l}10-79 x+\frac{1}{1} \\
40-2 m^{2}\end{array}$ & 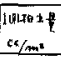 & 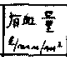 & 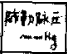 \\
\hline & & \multirow{2}{*}{1.559} & \multirow{2}{*}{ 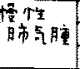 } & 曾 & $\frac{0}{10}$ & 18 & 5.40 & 468 & 123 & 101 & 1.16 & 7.294 & 92,5 & 70.0 & 61.0 & 28.0 & 42.5 & 2.73 & & & 23 \\
\hline & & & & \multicolumn{2}{|c|}{ 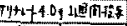 } & 17 & 5.50 & 506 & 225 & 102 & 1,22 & 7.330 & 440 & 72.0 & 482 & $2 \pi .6$ & 44.1 & 2.86 & 36.8 & 2.70 & 14 \\
\hline & & \multirow{2}{*}{1.496} & \multirow{2}{*}{ 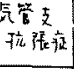 } & Ain & 0 & 17 & 6.02 & 530 & 137 & 116 & $\operatorname{lin} 4$ & 7.244 & 90.0 & 688 & & & 0.0 & & & & \\
\hline & & & & \multirow{2}{*}{\multicolumn{2}{|c|}{ 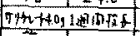 }} & 18 & 6.90 & 510 & 171 & 136 & 2.07 & 7.316 & 97.5 & 740 & 42,9 & 21.9 & 41.5 & 4.86 & $\begin{array}{l}408 \\
610\end{array}$ & $\frac{2.68}{4.76}$ & $\frac{15}{12}$ \\
\hline & & \multirow{3}{*}{1.461} & \multirow{3}{*}{ 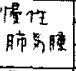 } & & & 2 & 551 & & & & & & & & & & & & & & \\
\hline & & & & 78 & 28.0 & 21 & 6.74 & 469 & 167 & 120 & $\frac{1.28}{231}$ & 7.323 & 80.2 & 60.0 & 62.0 & 1.3 & & & 24.8 & .33 & 28 \\
\hline & & & & \multicolumn{2}{|c|}{ 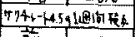 } & & & & & & & & & & 56.0 & 6.4 & 47.5 & 97 & 41.1 & 2.10 & 24 \\
\hline 2 & & \multirow[b]{2}{*}{1.467} & \multirow{2}{*}{ 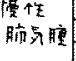 } & 帮1 & 0 & 22 & 7.08 & 473 & 180 & 30 & & 7.2 & 84 & 64,0 & & 5 & 45,0 & & & & 17 \\
\hline & & & & \multicolumn{2}{|c|}{$74+3+40928010+2$} & 22 & 7.80 & 510 & 209 & 164 & 2.63 & 7.320 & 91.5 & 70.0 & 47 & 21 & 46.5 & 7.34 & 87.4 & 430 & 15 \\
\hline
\end{tabular}

第 2 群 Sodium Salicylate+生食点滴静注短期の影䡈

\begin{tabular}{|c|c|c|c|c|c|c|c|c|c|c|c|c|c|c|c|c|c|c|c|c|c|}
\hline 症剧类号 & E & 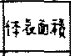 & 病名 & 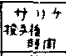 & at & 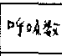 & 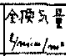 & $\begin{array}{l}\text { atust } \\
c e\end{array}$ & 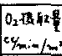 & 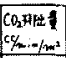 & 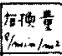 & 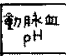 & 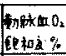 & 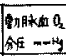 & 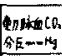 & 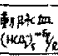 & 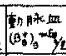 & 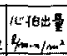 & 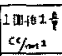 & 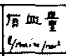 & 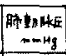 \\
\hline \multirow{5}{*}{14} & & \multirow{5}{*}{1.550} & \multirow{5}{*}{ 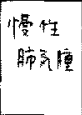 } & 椋 & 0 & 18 & 5.40 & 468 & 123 & 101 & 1.16 & 7.274 & 92.5 & 740 & 61.0 & 28.0 & $4 \geq .5$ & 2.73 & 33.0 & 2.62 & 23 \\
\hline & & & & $20 \pi$ & 45 & 19 & 7.23 & 593 & 186 & 150 & 1.75 & 7.336 & 93.2 & 76.0 & 56.0 & 31.2 & 44,0 & 3.59 & 39.0 & 3.4 & 17 \\
\hline & & & & 405 & 48 & 19 & 6.92 & 567 & 163 & 141 & 1.39 & 7.326 & 95.4 & 76.5 & 540 & 19.0 & 46.0 & 4.61 & 50.7 & 4.61 & 14 \\
\hline & & & & $60 \hat{n}$ & 43 & 18. & 2.19 & 623 & 162 & 141 & 1.92 & 7,718 & 956 & 75,0 & 53.5 & 25.0 & 42.0 & 3.39 & 37.7 & 296 & 15 \\
\hline & & & & \multicolumn{2}{|c|}{$6,0,+300 \mathrm{sec}(1)$} & & & & & & & & & & & & & & & & \\
\hline \multirow{6}{*}{15} & & \multirow{5}{*}{1.550} & \multirow{5}{*}{$\begin{array}{l}\text { 个曼性 } \\
\text { 脑苏䐺 }\end{array}$} & 萠 & $\Omega$ & 14 & 5.50 & 613 & 125 & 93 & 1.85 & 7,330 & 90.0 & 72.0 & 48.2 & 25.3 & 42,5 & 3.06 & 26.4 & 2.01 & 15 \\
\hline & & & & $20 \hat{2}$ & +2 & 13 & 635 & 762 & 196 & 138 & 2.01 & 7.352 & 94.5 & 74.5 & 42.5 & 22.9 & 420 & 3.04 & 312 & 2.30 & 12 \\
\hline & & & & 405 & 49 & 15 & 7.22 & 750 & 168 & 145 & 2.56 & 7.420 & 95,5 & 78.0 & 40,2 & 23.7 & 41.5 & 496 & 518 & 2.56 & 12 \\
\hline & & & & 600 & 45 & 16 & 7.05 & 688 & 161 & 139 & 2.27 & 7.336 & 41,5 & 74.0 & 47.0 & 240 & 402 & 293 & 29.6 & 2,27 & 9 \\
\hline & & & & \multicolumn{2}{|c|}{$5.5 \mathrm{f}+300_{t<}(\mathrm{z} \delta)$} & & & & & & & & & & & & & & & & \\
\hline & & \multirow{5}{*}[.4b]{} & \multirow{5}{*}{ 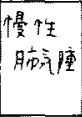 } & 蓓 & 0 & 21 & 5.51 & 382 & 118 & 108 & 1.02 & 7.313 & 80.2 & 60.0 & 62.0 & 24.3 & 482 & 1.88 & 24.8 & 1.33 & 28 \\
\hline \multirow{4}{*}{116} & & & & 205 & 38 & 16 & 6.60 & 597 & 164 & 148 & 1,50 & 7.358 & 86.0 & 62.0 & 63.0 & 28.0 & 47.2 & 4.43 & 568 & 2.19 & 23 \\
\hline & & & & 405 & $2 ?$ & 25 & 6.62 & 387 & 132 & 132 & 1.29 & 7.321 & 840 & 61.0 & 65.0 & $2 \pi .0$ & 45.0 & 4.51 & 50.9 & 2,61 & 28 \\
\hline & & & & 605 & 30 & 18 & 6.06 & 492 & 135 & 133 & 1.31 & 7.321 & $\$ 0.0$ & 61.0 & 650 & 26.7 & 45,0 & 5.98 & 65.1 & 2.65 & 28 \\
\hline & & & & $5.0 \mathrm{~g}+3$ & $O_{u k}(1)$ & & & & & & & & & & & & & & & & \\
\hline \multirow{5}{*}{17} & & \multirow{5}{*}{1.580} & \multirow{5}{*}{ 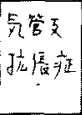 } & 菏 & $D$ & 15 & 4.71 & 497 & 110 & 99 & 1.00 & 7.211 & 71,2 & $6>0$ & 67.0 & 21.7 & 38.8 & 6.02 & 84 & 1.19 & 18 \\
\hline & & & & $20 \hat{~}$ & 38 & 17 & 4.99 & 464 & 157 & 134 & 1.60 & 7.280 & 78.2 & 6.4 .5 & 60.0 & 27.6 & 44.6 & 8.96 & 100 & 3.35 & 14 \\
\hline & & & & $A 0 \hat{B}$ & 26 & 17 & 658 & 612 & 170 & 159 & 1.88 & 7.288 & 95.5 & 63.0 & 58.5 & 27.6 & 44,9 & 2.86 & 15 & 2.86 & 15 \\
\hline & & & & $60 \hat{8}$ & 26 & 15 & 476 & 500 & 137 & 120 & 1.58 & $7,3 \times 1$ & 89.8 & 68.0 & 52,2 & 26.4 & 43.7 & 3.35 & $3 \pi$ & 2.64 & 14 \\
\hline & & & & $5.0 \mathrm{~g}+3$ & 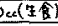 & & & & & & & & & & & & & & & & \\
\hline
\end{tabular}

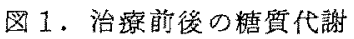

(サリチレート4.0〜 4.5g 7 日間経口投与)
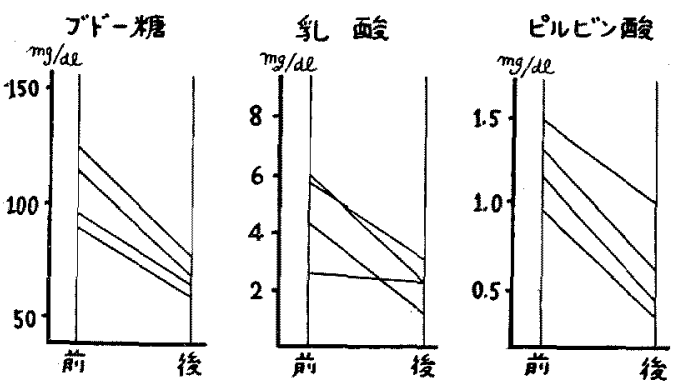

勱脈本幹平均血压少よび右公圧は下降の傾向を示 した。また肺血量およぴ平均肺循浐時間は，注と んど要化が認められなかつた。

糖筫代鳪においては，図1のごとくブドウ精， 乳酸㧈よび焦性ブドウ酸など Salicylate 連続投
与7日間に㧍いて，いずれも正常範囲の㚆動では あるが減少の傾向を示した（図1）。

2. 第 II 群（短期点滴静注の影響）：表 2 , 症 例 No. 14より No. 17まで sodium salicylate $4.0 \sim 6.0 \mathrm{~g}$ 学 $300 \mathrm{cc}$ 生理的食塩水に溶解し, これを30〜40分間にわたり点滴静注をおこない， 点滴終了後20分，40分方よび60分にわたり，心肺 諸動態を䚁察した。

Salicylate 血中濃度は点榈静注終了後いずれ も著明に上昇し，最低 $26 \mathrm{mg}$ per cent よ b 49 mg per cent 柰した. しかして, 症例 No. 14 および No. 15は Salicylate 血中浱度が，いず れ $40 \mathrm{mg}$ per cent 以上に造し，このさい，比

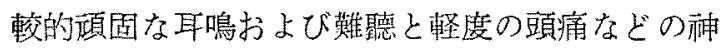
経症狀老訴え，これら副作用は点滴静注終了检さ 
らに 120〜 180分持続した。ただし，このさい第 1群にみられたような食欲不振, 覀心および呕吐 などの冒腸症狀は認められなかつた。

心肺動態の变化は，いずれも第I群より著明で あり，また変動も同様で点滴静注終了後60分にお いてもその变動梳とんど昰化が認められなかつ た。しかしながら症例 No.16はこれに反して分 時換気量, 酸素消費量および炭酸ガス排出量など いずれも増加したが，動脈血炭酸ガス分圧は点滴 静注終了後60分において，なお $65 \mathrm{mmHg}$ と上昇 し，また動脈血酸素飽和度および酸素分王もとも に低下し，肺動脈本幹平均血圧の下降もみられな かつた（表 2).

3. その他： acetyl salicylic acid 1 回投与の 影響および $4.0 \%$ 炭酸ガス吸入試験, またりーン テストの成績については考案のところで述べる。

\section{考案}

1919年 Barbour ${ }^{18)}$ 抢よび Devenis らが，正 常人にアスピリン $1.0 \mathrm{~g}$ 連続経口投与のさい に, 代謝元進 $(+6 \%)$ および炭酸ガス排出量の軽 度増加老報告している。一方, Coburn ${ }^{19)}$, Moore らが Salicylate 大量投与が急性リウマチ熱に 対する沿療葲として，その作用機序が下垂体副腎 系を介するものとして再認識されてきた。1954年 Wégria ${ }^{2)}$ らにより同疾患に対して, Salicylate 大量投与のさいに過呼吸, 頻脈および血液孷酸ガ ス合量の低下が報告されてより，呼吸器および血 液酸塩基平衡に及ほす Salicylate の作用機序が 種々检索されてきた。この過呼吸の成因についで, Cochran, Sproul17) らは, Salicylate 大量投与 のさいの末梢組織代謝に対する影響を，Eck 瘦 犬および Sympathicus 遮断後において検討し, Salicylate 血中濃度により組織の酸素消費は堌 減し, かつ組織酸素消費の増加と炭酸ガス産生の 上昇より，Salicylate 㹥直接末梢組織代謝に影 響し，このさいにみられる過剩換気は，孷酸ガス の組織内産生の結果, 2 次的に呼吸中枢を刺激す るためであるとした。
Rapoport ${ }^{3)}$, Boyle ${ }^{5)}$ および Farber ${ }^{13)}$ らは, 血液ガス・酸塩基平衡より， Salicylate 大量投 与のさいにみられる過換気は, alkalotic tendencyを伴なう primary hyperventilation とし た。さらに近年, Tenny おょび Miller') らは, 犬および正常人について， Salicylate 大量投与 のさいの呼吸および循環系に及ほすす影響を検討 L, i ) 正常動物で cysternal puncture で 500 倍のアスビリンを注入すると酸素消費の増加は特 にみられないのに，劇的な換気増加と2次的呼 吸性アルカロージスを生ずることより，呼吸中 权を直接刺激して過剩換気を生ずるものであり， aortic, carotid, chemoreceptor には直接関秝 がないこと，ii）クラーレ静注㧍よび decapitateした犬を， body respirator に入れて換気 を一定にしたさいにも，酸素搷取量の增加，肺胞 気炭酸ガス分玨の上昇および動脈血PHの低下など metabolic effect のあること. iii) ventilatory response で pace を維持出来ぬ場合（過剩換気 を生ぜしめ得場合）には，respiratory acidosisを招来することを確かめた。

Alexander ${ }^{8}$ らは, 正常人 3 例について, 炭酸 ガス吸入試験と Salicylate 大量投与を併用し, 呼吸中枢の炭酸ガスに対する感受性が增大するこ とを報告し，過剩換気を惹起する一つのメカニズ ムとしている。すなわち， Salicylate 大量投与 のさいにみられる過剩換気の成因を肺生理学的に 要約守ると，i）呼吸中枢を直接刺激して過剩換 気を惹起する。ii）metabolic effectによる2次 的の過剩換気，iii）孷酸ガスに対する呼吸中枢の. 感受性増加，などである。

Salicylate 大量投与が正常人および動物にお いて，過剩換気の結果 respiratory alkalosis 惹起すること，および呼吸中枢の炭酸ガス吸入に よる感受性が増大することより，Wegria9) らは, Anoxemia および Hypercapnia を伴なつた慢 性肺気腫患者について，血液ガス・酸温基平衡の 変動を Salicylate 大量点滴静注および経口投与 について観祭し，両群ともに宸酸ガス分住の減 
少, 動脈血 $\mathrm{PH}$ の上昇, 動脈血酸素飽和度の増加 など，慢性肺気腫患者の Anoxemia および Hypercapnia の改善を認め，また同一患者に対し て高濃度酸素吸入により増悪せる Hypercapnia をもとに戾すことを確かわている。

われわれも Anoxemia および Hypercapnia を伴なつた慢性肺疾患々者に対して，大量点滴静 注および経口投与について検索した結果，分時換 気量, 酸素摄取量, 炭酸ガス排出量の増加と, 有効 肺胞換気率および有効肺胞血流嘌など，ガス血液 分布障害の改善をみた。また血液相では動脈血炭

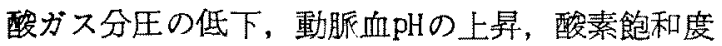
の上昇をみ， $\left(\mathrm{B}_{\mathrm{B}}^{+}\right)_{\mathrm{B}}$ および $\left(\mathrm{HCO}^{-}{ }_{3}\right)_{\mathrm{S}}$ には一定 の傾向なく, respiratory acidosis の改善がみら れた。この改善は Wégria9らら報告しているご とく, Salicylate 大量投与により生じた過剩換 気により炭酸拨ス排出量の増加と, 呼吸中枢の炭 酸分スに対すと感受性堌加とがあいまつて，2次 的に呼吸性アルカロージスを惹起したためと思わ れる。

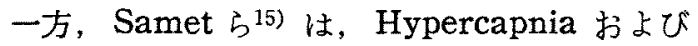
Anoxemia のある肺気腫患者について, Salicylate 大量投与のさいに，換気量，酸素消費量およ び炭酸ガス排出量は増加したが，動脈血の炭酸ガ ス分圧, 酸素飽和度およびpHは変化のない症例が あることより, metabolic effect による2次的 の過剩換気であるとし，換気諸量および血液ガス 諸量の改善がないことより，Wégria らの唱えた

図 2.サリチレート点滴静注無效例 症例No. 16
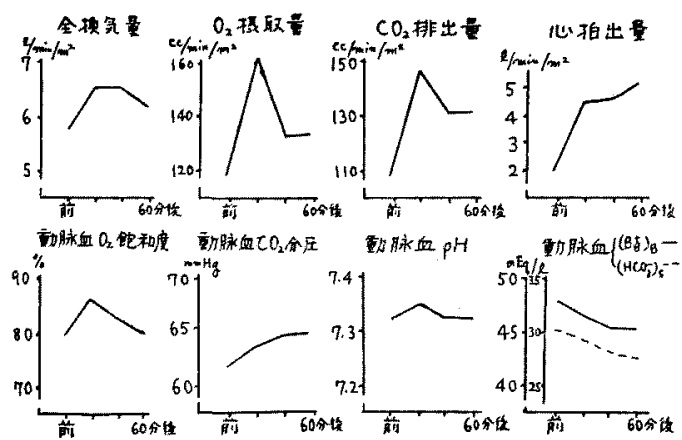

respiratory acidosis の改善を否定している.

われわれも 1 例ではあるが，表 2 症例 No. 13， 図2のごとく同種疾患々者に Salicylate 大量点 滴静注したさいに，分時換気量，酸素消費量およ び心拍出量は増加したが，動脈血の孷酸ガス分 圧，酸素飽和度および $\mathrm{pH}$ 上昇しなかつた症例 を経験したことは， Samet らの報告とともに， Salicylate 大量投与が肺不全患者の気相㧈よび 血液相の改善に対して，必ずしも有効であるとは 言い得ないが，われわれの大部分の症例に対して はWégria と同様に気相㧈よび血液相の改善が みられたことから， Salicylate の心肺機能に対 する作用機序は過剩換気が主役を演じているもの と考えられる。

この過剩換気の成因にかんしては，上述のごと く現在までに正常人うよび慢性肺気腫患者に対し て検討され，i）面接呼吸中枢の刺激による， ii) metabolic effect による2次的の増加，iii） 炭酸ガスに対する呼吸中枢感受性の増加があると されている。

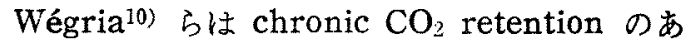
る肺気腫患者について，血液ガス・酸塩基平衡よ りdepressed ventilatory response があるにか 〉わらず跑脈血孷酸ガス分王が減少し，また動脈 血pHが上昇することにより，Hypercapnia およ び Anoxemia を伴なつた肺気腫患者においても， 健常者および正常大と同様に呼吸中枢および宸酸 ガスの呼吸中枢に対する感受性の増加を唱えてい るが，一方，Samet ${ }^{16)}$ は同様疾患に対して，3 $\%$ \%び $5 \%$ 炭酸ガス吸入による呼吸中枢の感受 性を Salicylate 投与前後において，換気量およ び有効肺胞換気量の増加率と動脈血炭酸方ス分圧 の増加の割あい(いわゆる，呼吸中枢の炭酸ガス 反応曲線）および動脈血pHの増加の割あいの好転 がみられないことより, Alexander らのいう健常 者における炭酸ガスに対する呼吸中枢感受性の増 加を否定している。

われわれも同種疾㭧々者について，表 3 症例 No.18より No. 22について, Samet らと同じ 
表3. 第3群 アセチルサリチル酸 1 回投与と $\mathrm{CO}_{2}$ 吸入の影響

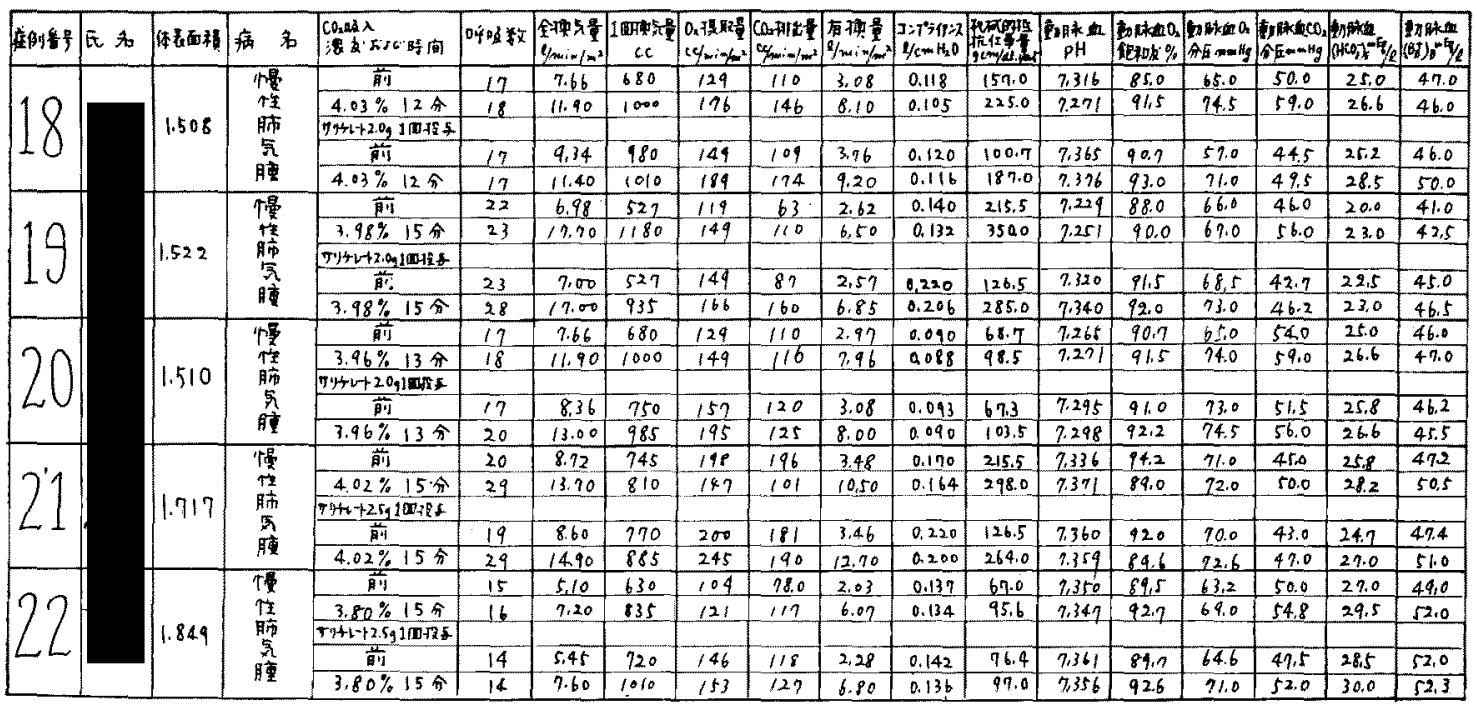

図 3. $\mathrm{CO}_{2}$ 吸入試験 経口 $2 \mathrm{~g} 1$ 回 症例 No. 19

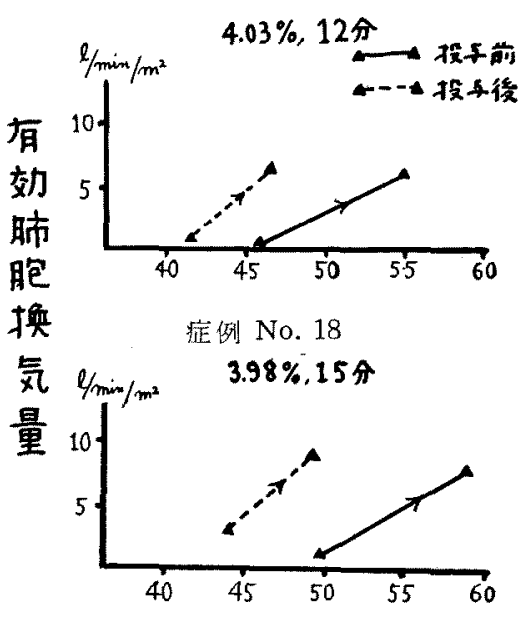

乵脉血 $\mathrm{CO}_{2}$ 介圧

く, 約 $4 \%$ 炭酸分ス吸入による呼吸中枢の感受性 を検討し，Alexander らが報告したごとく，呼 吸中枢に対する炭酸ガス反応曲線が正常人とほら゙ 同じように，図3のごとく Salicylate 服用後上 昇の傾向を示し，その呼吸中枢に対する感受性の 增加を認めた（表 $3 ，$ 図3).
図 4. 治嘹前後の换気力学諸量

(サリチレート 2.0〜 2.5 g 1 回投与)
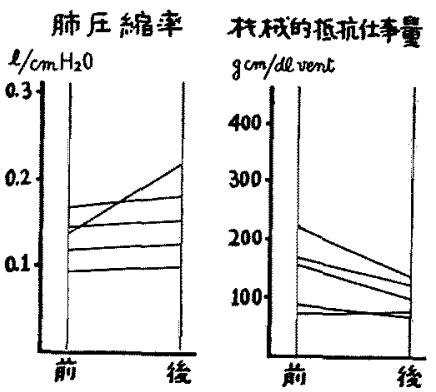

気道直径

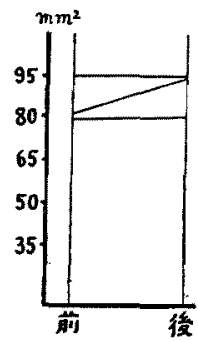

しかしながら，加るる肺疾患々者に揖いては， 上述の i) ii) iii) のほかに, hyperventilation を生ぜしめる原因として気道障䈏の変化によつて も生じるものである。かっる観点より, acetyl salicylic acid 2.0〜 2.5 g 1 回経口投与前後の

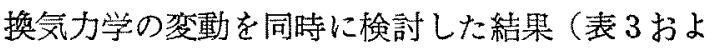

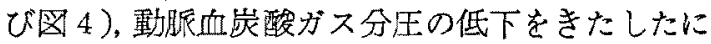

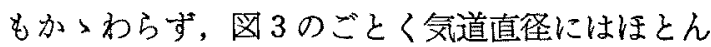
ど変化はないが, 胸膑内压の変動は䭪加し, 換気 仕事量のいちじるしい増大にうちかつて 1 回換気 量も增加した。このことと上述の崖酸ガス民応曲 
線の好転よりみて, Salicylate 大量投与のさい にみられる換気量の増加は，中枢性の強力なる Ventilatory drive による換気促進作用の結果 によるものと思われる（表 $3 ，$ 因 4).

また一方, acetyl salicylic acid $4.0 \sim 4.5 \mathrm{~g}$ 7 日間連続服用したさいの, 動脈血ブドウ糖, 乳 酸および焦性ブドウ酸の推移は，図 1 のごとく， 正常範囲の変動ではあるがいずれも減少したこと は，これら症例の著明な酸素提取の増加とあいま つて好気的な解糖過程の進行，換言すれば代謝性 の影㗽もある程度関与するものであるうと考えら れる。

さらに Salicylate は急性期のリウマチ性疾患 に対する治療莧として, Selyeにより下垂体副腎 系の重要性が唱えられてより, Salicylate はス テロイド・ホルモンと同じように下垂体副腎系を 介するものとするという報告がみられるようにな つた20). Salicylate 大量投与のさい，血中好酸 球数，副腎コレステロールおよび副腎アスコルビ ン酸は減少し，尿中 17-KS, Reducing steroid は増加する20). Cochran ${ }^{19)}$ は1日 5.0 gのアス ビリンを与えたところ軽度のCushing 症候群を きたした例を報告している。また Smith らは， リウマチ患者にACＴHを与えると尿中ステロイ トは増加するが，Salicylate は増加しないとし ている，Kelley17) は急性期リウマチ性患者抢よ び健康人について検討し，リウマチ性患者では尿 中ステロイドは増加しないが，健康人では増加を 認为ている.

われわれも肺気腫および気管支搪張症 4 例につ いて, Salicylate 3.5 4.0g 4 回分服 7 日間投 与前後において，血中好酸球数抽よび尿中 17-KS を検討した結果，図 5 のごとく血中好酸球数の減 少と, 尿中 17-KS の增加を認めた。すなわち肺 不全患者では健常人または正常動物と同じよう に, Kelley および Cauvenberg らの報告のご とく，直接または間接に下垂体副腎系を刺激し ていると考えられる。しかして近時 Austen 20) ら
図 5.治療前後の副腎機能
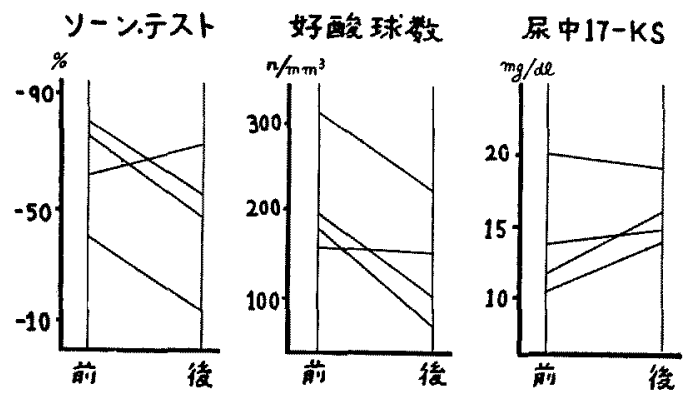

により甲狀腺機能低下作用のあることが報告され たことは，われわれの経験した症例 No.16のよ うに， Salicylate 大量投与により分時換気量お よび酸素消費量の増加があるのに，動脈血炭酸が ス分圧の上昇など血液ガスの好転がみられず，ᄂ かも患者の自覚症狀の好転がみられたことは， Salicylate の心肺機能に対する作用機序は，hyperventilation が 主役ではあるうが心肺機能に 対する side effectsとしてみるさいに興味あるこ とと考える。

Salicylate 大量投与のさいの中毒症狀出現に かんしては，現在までに多くの報告があるが12)13) 14)16)，種々検討の結果，它のうち特に胃腸症狀お よび神経症狀発現時の血中濃度のほぶ25mg per cent 以上を目標に，点滴静注および経口投与 1 回，さらに経口投与長期にわたり使用したさいの 血中㴗度，体重あたり，患者分布および自覚症狀 の発現（胃腸症狀および神経症狀）の程度は図 6 のごとくであり, Salicylate 血中濃度20〜 $28 \mathrm{mg}$ per cent において, Graham, Parker ${ }^{4)} ら$ も指

园6.サリチル酸の效果

\begin{tabular}{|c|c|c|c|c|c|}
\hline 段与量 & 血中港古 & 患者分第 & & 作 用 & 改善 \\
\hline \multirow[t]{2}{*}{$\begin{array}{l}m \mathrm{mg} / \mathrm{kg} \\
100\end{array}$} & \multirow[t]{2}{*}{$\begin{array}{l}\text { mg \% } \\
401\end{array}$} & \multirow{3}{*}{$\begin{array}{l}: \\
\vdots \\
\vdots \\
:\end{array}$} & $H$ & $\begin{array}{l}\text { 种経症狀 } \\
\text { 胃渴症狀 }\end{array}$ & \multirow{2}{*}{$H$} \\
\hline & & & + & 胃渴症䘞 & \\
\hline${ }^{75}$ & 20 & & \multirow{2}{*}{ \pm} & \multirow{2}{*}{ 殆んどなし } & $H$ \\
\hline \multirow{2}{*}{50} & \multirow{2}{*}{10} & \multirow[t]{2}{*}{88.} & & & + \\
\hline & & & - & & $\perp$ \\
\hline
\end{tabular}


摘しているごとく，中毒症狀の発現なく，心肺諸 動態の改善がみられた。しかして患者の胃晹症狀 に対しては收㩯劑を併用することによつて，また 自覚症狀に耐えられ場合には Salicylateを服 用中止，または減量することにより目的を達し得 た（図6).

\section{おわりに \\ 以上，われわれは，肺不全患者の治瘵の対策の} 一つとして， Salicylate 大量投与による変趿㧍 よび効果を，主として心肺諸趿態を中心に検討 L, 1). Salicylate $5.0 \sim 6.0 \mathrm{~g}$ 点滴静注実施後 20分より，換気量，酸素摄取量の増加，動脈血炭 酸ガス分仕の低下，動脈血pHおよび酸素飽和度の 上昇をみた。また心拍出量の増加，肺動脈本幹平 均血圧の下降を示し，かつ体血生は，注ぶ不变で あつた２）しかしながら，点滴静注実施後、換 気量, 酸素摄取量および心抬出量の增加にもか

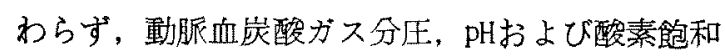
度の变動を生じない症例を経験したこと，およ び，糖質代謝より代謝性影響を認めたことは，肺 不全患者の Anoxemia および Hypercapnia を 改善する治療として, 必ずしも有效な作用を持ち 得ないことを示唆している．3） Salicylate（ア スピリン. 2.0〜 5.0g) を分服経口 1〜 7 日間投 与のさいにも，1)とほぶ同様の变動を示したが， 血中濃度がほぶ15mg per cent 以下のもので は，気相うよび血液相におよ称效果はほとんど 認められなかつた４）炭酸ガス吸入試験による 呼吸中枢の感受性を検討し, Salicylate 大量投 与によつて呼吸中枢感受性の増加を浔めた。5)

Salicylate 大量投与と中表症狀（特江食欲不振， 悪心, 耳鳴および難㯖)および心肺諸勤態の改善 がみられる量とを検討し, pro kg 60〜70mg (血 中濃度20 30mg per cent）が妥当と考えられ る.6) Salicylate 3.0〜 4.0 g 分服 7 日間服用 前後において副腎機能を椮查した結果，下垂体副

繁系が束激されているという結果を得た。

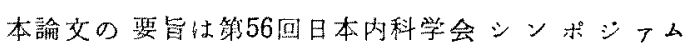

\footnotetext{
“脯不全の対嚓”として発表されたすのの一暗である。
}

\section{主要文献}

1) Wright, S.: The mode of action of certain drugs which stimulate respiration, J. Pharmacol. \& Exper. Therap., $54: 1,1935 .-2)$ Wégria, $R$. et al.: Salicylate therapy in acute rheumatic fever, J.A.M.A., $129: 485,1945$. 3) Rapoport, S. et al.: The effect of salicylates on the electrolyte structure of the blood plasma. 1. Respiratory alkalosis in monkeys and dogs after sodium and methyl salicylate; the influence of hypnotic drugs and of sodium bicarbonate on salicylate poisoning, J. Clin. Invest., $24: 759,1945 .-4)$ Graham, J.D.P. et al.: The toxic manifestations of sodium salicylate therapy, Quart. J. Med., 17 : 153, 1948. - 5) Boyle, M.N. et al.: The effect of sodium salicylate on the acid-base balance of the blood, J. Clin. Invest., $24: 783,1945 .-6$ ) Singer, R.B.: The acid-base disturbance in salicylate intoxcation, Medicine, 33:1, 1954. - 7) Cochran, J.B.: The respiratory effects of salicylate, Brit. Med. J., 2 : 964, $1952 . \quad-8$ ) Alexander, J.K. et al.: Modification of the respiratory response to carbon dioxide by salicylate, J. Clin. Invest., $34: 533,1955 .-9$ ) Tenny, S.M. et al.: The respiratory and circulatory actions of salicylate, Am. J. Med., 19: 498 , 1955. - 10) Wégria, R. et al.: Effect of salicylate on the acid-base equilibrium of patients with Chronic $\mathrm{CO}_{2}$ retention due to pulmonary emphysema, Am. J. Med, 19:509, 1955. - 11) Mack, I.: Cor pulmonale, Clin. Cardio. Pulm. Physiol., 513, 1957. - 12) Friend, D.G.: Current concepts in therapy, New Engl. J. Med., $257: 77,1957$. - 13) Farber, H.R. et al.: The effect of therapeutic doses of aspirin on the acid-base balance of the blood in normal adults, Am. J. M. Sc., $217: 256,1949$. - 14) Michael, H.: Encephalopathy during salicylate treatment of acute rheumatism, Brit. Med. J., 5051 (26) : 979, 1957. - 15) Samet, P. et al.: The effect of salicylates upon the ventilatory response to carbon dioxide in patients with pulmonary emphysema and hypercapnia, Am. J. Med., $24: 251,1958$. 16) Goodman, L.S.: The pharmacological basis of therapeutics, 224, New York MacMillan, 1955. - 17) Kelley, V.C.: Resent advances in its pharmacology and clinical use: Mechanisms of therapeutic actions of salicylate, St Louis medical society, 1957. - 18) Barbour, H.G. et al.: Arch. Intern. Med., 24: 617,1919. -19) Coburn, A.F.: Salicylate therapy in rheumatic fever, Bull. Johns Hopkins Hosp., $73: 435,1943 .-20$ ) Austen, F.K. et al.: Salicylate and thyroid function, J. Clin. Invest., $37: 1131,1958$. 